\title{
Aristotelism of Difference
}

Jesús de Garay

University of Seville (Spain)

$5^{\text {th }}$ March 2007

\section{The Aristotelisms of Unity}

It is well-known why Aristotelism was abandoned and why, still today, it continues condemned to marginalization. Modernity was constructed against Aristotelism. This does not mean that modernity was constructed on the ruins of Aristotelism -in fact the Aristotelism of the 16 th century ${ }^{1}$ represents perhaps the most brilliant moment of its history- but it means that the modern proposal raised like a more credible alternative and a more rigorous one regarding Aristotelian scholasticism.

Aristotelism became then synonymous of pre-modern or anti-modern. And this perception continues being true today. The guilty verdict of modernity against Aristotle has been more forceful in the West than the anathemas thrown by the bishops of the 13th century. Algazel (Marmura: 1997) or Ibn Taymiyya (Hallaq: 1993) were able to expel Aristotle from Islamic thought, but, in Western culture, the criticisms coming from Hobbes, Descartes, Bacon or Galileo were even more effective in dismantling Aristotelism.

Nevertheless, the condemnations of Aristotle, as well as their exaltation by fervent Aristotelians, have not always been based on texts from Aristotle, but rather on later Aristotelisms. In following, I will pay special attention to one aspect of these misunderstandings.

Specifically, there is a central doctrine in Aristotle that usually isn't recognized in its importance, and that even sometimes happens to be ignored. I am talking about the affirmation of the difference and the plurality. Without a doubt, it is a question of emphasis, since it is impossible to speak about Aristotelian philosophy without recognizing the relevance that differences have in Aristotelian writings.

However, if the texts of Aristotle are read at the light of later Aristotelisms, it is immediately understood why this affirmation of the plurality and the differences has been relegated to the backseat. This is because, in religious cultures, 'Aristotelisms' have been developed having in mind a very marked sense of a single entity. A firm faith in a single God is shared by Judaism, Christianity ${ }^{2}$ and Islam. And even in Roman paganism, the Neo-Platonic speculations culminate in a full affirmation of the One.

And, as a result, the Roman, Medieval and Renaissance horizons are defined by Unity. And more specifically, by the singleness of God. In the end, from Ancient

\footnotetext{
1 'L'influenza di Aristotele non declinò durante il Rinascimento, ma di fatto si accrebbe in maniera enorme" (Ch.B. Schmitt: 1985, La tradizione aristotélica: fra Italia e Inghilterra, Bibliopolis, Napoli, p.12)

${ }^{2}$ About some attempts to think philosophically the Trinity from Christian monotheism and platonism, Cf. W. Beierwaltes: 1980, Identität und Differenz, Klostermann, Frankfurt a.M., in particular concerning Marius Victorinus, John Scotus Erigena, Meister Eckhart, Nicholas of Cusa and Hegel
} 
Rome to Renaissance Florence everything is reduced to a first single being from which all plurality comes. The concept of 'creation of the world' will be the manner in which diverse theologies -the first one, the Judaism ${ }^{3}$ - will conceive this subordination of plurality to unity.

Unity will appear in all cases not only as the most essential characteristic of the physical universe but also -and specially- as a requirement of thinking. All speech has to aspire to coherence and unity. One way or the other, philosophy is expected to carry out a task of unification and synthesis, from the multiplicity of phenomena to the unity of principles. And even up to the point of arriving at an only and single principle. Perhaps this Neo-Platonic imperative continues reappearing today as an irrefutable requirement of thinking. For that reason, Aristotle has never look sufficient. An insufficiency that had to be refuted or, in the best case scenario, had to be completed.

However, throughout the Roman centuries, we find a common doctrine shared both by Platonic and Aristotelian thinkers, in which their respective discrepancies are blurred (Hegel: 1997, 12). The limits are so smudge that some platonic and hermetic writings got to be attributed to Aristotle, fundamentally from Plotinus and Proclus. It is the case of the Liber de Causis (Ancona: 1995) or of the Theology of Aristotle, which masked the Aristotelian rejection of platonic unity. This way, in the course of the centuries, Aristotelism lost which was perhaps its most characteristic and specific feature versus Platonism, that is, its criticism of unity and its defense of plurality.

The medieval doctrine of the transcendentals - that is usually attributed to Philip the Chancellor (Libera: 1993, 379-382) at the beginning of 13th century- blessed the equivalence of one with being, of truth with goodness. The horizon of thinking, knowing, and being is governed by oneness. Plurality and difference are subordinated to the first oneness of thinking and being. As a matter of fact, no doctrine can be considered more opposed to Aristotelism than this one.

Among Renaissance thinkers we find a variety of Aristotelisms. Next to the Tridentine Thomism of the Counter-Reformation, there were other scholastic Aristotelisms -such as Averroism, Albertism, Ockhamism, or Scotism-. The discrepancies among them were deep sometimes, despite their common profession of Aristotelism. And, of course, Aristotelian faith was present both in the Counter-Reformation as in the Reformation (Schmitt: 1985, 19-22, 75).

At any rate, next to Renaissance Aristotelism, we find the best known and most popular Antiaristotelism of the humanists (Kristeller: 1993; E. Garin: 2001; Granada: 2000). In fact, more than a criticism against the historical Aristotle, it was actually an acid rejection of scholasticism. At the time, the criticism was the one that has always been made to scholasticisms, and that it is still made today: that, whilst scholastics become entangled in the bitterest debates, they just achieved disorienting the ordinary man in its action. What Erasmus or More detest from scholastic academics

\footnotetext{
${ }^{3}$ A full exposition of Philo's thought (and in particular about the determining influence of the Jewish thought in the neoplatonism) can be found in H.A. Wolfson: 1948, Philo.Foundations of Religious Philosophy in Judaism, Christianity and Islam, Harvard University Press, Cambridge Mass. More recently, cf. R. Radice: 1989, Platonismo e creazionismo in Filone di Alessandria, Vita e Pensiero, Milano
} 
is their conceptual pedantry, which moves away from everyday life. While they immerse themselves in their abstractions, all concrete and daily life passes by them without them even realizing.

Nevertheless, it is well known the Aristotelian interest on individuality and distinctiveness, which does not match the criticisms coming from humanist thinkers. And not only in their writings on biology, but mainly in their writings on ethics, rhetoric, poetics, or politics. Maybe, quite to the contrary, what we find here is a dispersion of particular indications, ordered with unequal success. In fact, Renaissance writers were aware of this Aristotelian interest in the individual action, and a clear proof is the attention they paid to these practical philosophical writings, to the detriment of other works, such as the Analytics.

However, Renaissance Christianity was reading the practical philosophy of Aristotle from Stoic and Augustinian concepts that had been systematized by Latin scholastic. Concepts like eternal law, natural law, or moral conscience were too rooted in the intellectual horizon of the time as to rendering it impossible reading the Nichomachean Ethics out of them (see e.g. Aquinas: 1950). That way, common moral doctrine placed God as the Supreme Legislator of the physical universe, of human society, and of each individual person, in such a way that the unity of the creation was guaranteed.

Renaissance culture is basically a Christian culture and, therefore, monotheist and convinced of the unity of all reality. Even more, the Humanist allergy to professorial theological disputes points toward a firm conviction in the unity of all religions and cultures. Cosmopolitism and pacifism are usual in these years. Indeed, Cusa or Pico look for finding a way to save the contradictions within such unity. As it happens in Leibniz two centuries later, unity of nations and religions is included in the unifying ideal of many Renaissance thinkers. And Christianity is portrayed just as the complete synthesis of all particular truths of each and every religion and culture (Granada: 2000, 83-118). The Renaissance is a culture of unity.

So, in the middle of the 17th century, when Aristotelism fades away from the philosophical scene and is relegated to marginalization, Aristotle's strong expressions against unity have merit little attention.

\section{The Aristotelism of Difference ${ }^{4}$}

Nevertheless, if we pay close attention to the texts of Aristotle, we find a profound rejection of the unification of all reality in a first Unity ${ }^{5}$. There is not an only Unity or Good from which all things come, neither a first Substance, nor a first Subject, nor a Being who summarizes and integrates within himself all beings. Neither the One (Met., XIV-4, 1091b16-37), nor the Good (EN., I-6, 1096a23-34), not the Being (1096a23-28) have any reality beyond the fact of being mere abstract concepts.

\footnotetext{
${ }^{4}$ Perhaps the most complete classification given by Aristotle on the difference is the exposed in Met. X-3, 1054b 13 - 1055a 2. See also Met. V-9, 1018a12-19

${ }^{5}$ I have examined some texts of Aristotle concerning the concept of difference in J. de Garay: 2001, La diferencia en Aristóteles. Anales de la Real Academia de Doctores 5, 251-260.
} 
The Aristotelian universe is a plural and differentiated universe, although ordered. And of course, the criticism of Aristotle to Unity doesn't go only against the One of platonic philosophy, but it could also be argued against the monotheist God, the materialistic Matter, or the free and self-creator Subject. As far as Aristotle is concerned, there isn't One or Being with capital letter, but a plurality of substances, and a diversity of senses of being and of unity. Neither there is a first Good in which all other goods participate.

Possibly the topos of Aristotelism where the clearest expression of this upholding of the difference can be found is the doctrine of the eternity of the world. If differences have been there since always, if plurality isn't something derived but that is first, then the world has not been created but is eternal. The Aristotelian rejection of the demiurge of the Timeo was nothing more than one of the consequences of its refusal to assume the platonic metaphysics of the One and the Dyad. Nevertheless, medieval Aristotelism transformed the discussion on the eternity of the world into a debate between faith and reason, where both Averroists and Anti-Averroists argued.

The Gamma book of Metaphysics is the place where the irreducibility of the differences to the unity is more explicitly proclaimed (Met., IV-4,1007b18-22) ${ }^{6}$. The affirmation of the difference of substances is as primary as the principle of non contradiction (Met., IV-4,1008a20-27). The first principle is not the One but the plurality. The horizon of thinking is not the unity but the diversity of the logos. The unity of the logos presupposes the differences within reality.

Without a doubt Aristotle is not a postmodernist avant la lettre. Alongside the affirmation of the differences there is always the unity of the logos and other meanings of the unity. But, at any rate, what Aristotle clearly is not is a Neo-Platonic. His philosophy is the antithesis of the One from Plotinus or Proclus.

Consequently, for him all causes are not reduced to one. And in general, not everything has a cause. Everything does not have a logical and necessary reason which explains why something has happened in one way and not otherwise. Reality cannot be reduced to reason, because then it would be necessary to arrive to one and only first reason, in which all reasons and all beings would be transformed. Neither every thing real is rational, because then there would be one and only first principle of all, and that is impossible. The farthest reason is capable of arriving is ordering all differences in a cosmos. But that unity of order is never a constituent of the differences.

This irreducibility of plurality versus unity is another naturalistic version of the eternal return vindicated by Nietzsche. Difference is irreductible to unity. The divine One is displaced to an indefatigable and cyclical Nature that never stops working in a differentiating manner.

On the other hand, concerning mathematics, there is not an absolute disqualification. His criticism aims at the idea that everything real can be measured by unity ${ }^{7}$. If all number comes from unity, and if everything is number, then everything comes from the One. That's why he insists on limiting the role of mathematics to a function of

\footnotetext{
${ }^{6}$ A systematic critique of the One can be found in Phys., I-2, 185a20--187a11

${ }^{7}$ Cf. Met. XIV-1, $1087 b 33$
} 
measurement. To measure is always to measure something, and that something precedes measurement. Therefore, everything isn't measured, everything isn't number. The reality of measured things is diverse of the same measurement. Number makes possible the equivalence between all things. The equal sign allows uniting the most heterogeneous, by means of the expression of its relations. But what Aristotle emphasizes is indeed that there are differences behind such equality, not that equality is false or that mathematics might be useless. But, furthermore, he emphasizes that there are differences which precede measurement, and they are neither measurable, nor equalizable, nor matematizable.

The affirmation of differences is also visible in its well-known formulation of the diversity of the senses of being. It is not necessary to look for the sense of being because there is not a single signification of being. The inquiry for the sense of being lacks an answer. Instead there is a plurality of meanings of being. The diverse aspects of reality cannot be reduced to a unique one. Accident, falseness, or possibility are as real and relevant as substance, necessity, truth, or act.

In particular, potentiality is a sense of being that is never reduced to an act (Met., IX-3, 1046b29-1047a24). Not only it exists what now is, but it also exists what can be, but still it is not (and perhaps never will be). Even more, all the Aristotelian analysis of human action, freedom and practical reason demands the reality of potentiality (EN., VI-4, 1139b37-1140a 2).

On the other hand, the accident (to symbebekos) shows that what is meaningful is not only the identity of the substance, but also the diversity of qualities and movements, places and times, amounts and possessions. The meaning of the accidents is not the sense of the substance, but in spite of that they are not nonsense.

In a similar way, the accidental - the being kata symbebekos - has also meaning, insofar as it makes possible human action (EN., I-3,1094b11-27). The indetermination of the physical universe makes it possible for man to act in a no predetermined way. As Epicurus learned well from Aristotle, a certain deviation of necessity (the clinamen of Lucretius) is required in order to make human freedom possible. Without the indetermination of accidentality there would be neither contingency nor freedom.

\section{Dialectics, Rhetoric and Practical Philosophy}

Aristotle has been usually considered - and rightly - as a symbol of science. Consequently later Aristotelisms have read Aristotelian texts under the prism of science. Scientific demonstration was deemed the paradigm of knowledge. Therefore all knowing or thinking which would not adjust to scientific reasoning was seen as preliminary to science. Although Aristotle might have been abandoned, this faith in science as a paradigm of knowledge has not disappeared, at least in the so called Western world.

Nevertheless, Aristotle had analyzed other forms of knowledge out of science. It was the case of dialectics, rhetoric, poetics, ethics, politics, etc. ${ }^{8} \mathrm{We}$ are referring to

\footnotetext{
${ }^{8}$ Alfarabi: 1953 (Catálogo de las ciencias, CSIC, Madrid) carried out a systematization of the Aristotelian forms of knowledge, that decisively influenced Islamic philosophy (cf. D.L. Black: 1990, Logic and
} 
knowledges that pay attention to what is contingent and, therefore, are art rather than science. Their scope is different from nature, which can be characterized by occurring always or most of the times.

When confronted with different realities, knowledge also has to be different. For that reason, human action requires different types of knowledge. Perhaps, in the past century, it has been Heidegger the first one -in the Natorp Report- who has attracted attention to the peculiarity of the practical philosophy of Aristotle (Heidegger: 2002). And Gadamer has known to develop those suggestions throughout all his work ${ }^{9}$.

Theoría does not encompass the Aristotelian exposition in its entirety. Next to the robust identity of scientific truths, nothing is so differentiated as human action, as it is always performed from a new starting point. Each singular action comes from differentiated habits that constitute like a second nature - different for each individual -. If actions are conformed by habits, and if habits are continuously transformed through each action, no action is exactly identical to another one (EN., VI-8, $1141 \mathrm{~b} 32-1142 \mathrm{a} 1 ; 1142 \mathrm{a} 25-28)$. Opposed to nature, which is an identical principle of movement and rest, the source of human action is in reason, which is a potency of opposites (Met., IX-2, 1046a36-b24).

Human action takes place in an environment differentiated by circumstances, that is to say, by accidents and the accidental. In human action accidents such as place, position, time, habit, quality, amount, passion, etc. are all relevant. And they are also relevant -and by far- coincidences and chances, as well as sporadic and unusual occurrences. That something happens a single time due to an accumulation of coincidences can be essential to make a decision that otherwise would never had been taken.

In summary, if we are trying to think the difference, then it is necessary to think action. In other words, if we observe reality sub specie identitatis, meaning from the perspective of identity, then the most appropriate place to look for identities is the physical universe, where regularities and necessities abound. But if we observe reality sub specie differentiae, then human and social reality comes up to the foreground. They are two different forms of wisdom and rationality: the world can be seen focusing on identities or on differences. They are two different aspects of reality. The same reality but considered from two different points of view. As the Medieval Latins say, the obiectum formale is different.

But identity is not the only aspect to which we pay attention. That is precisely the huge prejudice that, since Plato, ballasts our conception of knowledge. In fact, we pay attention to many other aspects of what is real, and very particularly to singularity, to what is unique, accidental, and circumstantial. Moment and fitting place are two aspects of reality that have the utmost interest for human beings. Estimating the

Aristotle's Rhetoric and Poetics in Medieval Arabic Philosophy, Brill, Leiden), on Jewish thougth (specially through Maimonides), and also on the Latin philosophy, mainly through the version of Dominicus Gundissalinus (M. Alonso ed.: 1954, De scientiis, CSIC, Madrid).

${ }^{9}$ I have studied the Gadamer's Aristotelism in J. de Garay: 2005, Hermenéutica y formas aristotélicas de racionalidad. In T. Oñate (ed.): Hans-Georg Gadamer: Ontología estética y hermenéutica, Dykinson, Madrid, pp. 329-354 
right circumstance is essential. Science does pay attention to identity, or at least to what gets close to identity, such as statistical regularities. For that reason, today we have learned to turn into science the old arts of medicine, psychology, sociology, economy or politics. But seeing or listening to somebody from the perspective of identity has little to do with seeing him or listening to him from the perspective of the difference.

Thinking the action is thinking what is singular (EN., III-1, 1110b6-7; VI-7, 1141b15-16). The Aristotelian concern for the individual does not finish with "Socrates" or "Callias", or with the empirical facts that nourish scientific argumentation. The individual being for Aristotle is, above all, the human action. Accordingly practical rationality can never be universal science (EN., I-6, 29-32), insofar as it lacks the minimal identity required for science.

If other forms of knowledge are examined in light of practical rationality, then it can be perceived how, not only ethics or politics, but also rhetoric or dialectics constitute forms of rationality that are different from science. Indeed in dialectic and rhetorical speech action plays a central role. Of course, for Aristotle science is also action, because all intellection is action: energeia, praxis (Met., IX-6, 1048b22-36). But in the scientific speech, the particularity of the human action is erased to open the way to impersonal scientific knowledge. Nevertheless, dialectic and rhetorical speeches are always circumscribed to the individual.

Dialectic speech is always a speech of many voices: that is to say, a discourse spoken and thought from different perspectives. The interlocutors are particular individuals who express themselves from a particular horizon, and who ask and respond according to their historical and cultural circumstances. In dialectics they are confronted simultaneously different senses of the same.

Aristotelian dialectics represent the other face of the principle of non contradiction. If in this principle the unity of coherence is required, the unity of each meaning that makes possible the unity of speech (Met., IX-6, 1048b22-36), dialectics instead is always open to diverse interlocutors, speeches, and meanings (Soph.Ref., 19). The unity of scientific speech is preceded by the diversity of dialectic speeches. For that same reason, Aristotle considers a central function of dialectics the preparation for science (Top., I, 101a25-b4). In the dialectic speech we do not find a unity of meaning but a diversity of significations. The great value of dialectics is to be able to think simultaneously different senses of the same. Furthermore, the meaning of the speech of any interlocutor keeps changing as the dialogue advances, because it is transformed by the questions and answers already expressed. Meaning is always something changeable, and nevertheless it is possible to think with this continuous variation of meanings. The Faktum of the dialogue proves that the mind can think the plurality and the diversity of particular senses.

The different consideration of Aristotle's dialectic versus Plato is another manifestation of the Aristotelian allergy towards the unity. Rejection, criticism, dialogue, and discussion do not culminate necessarily in the unity of the conflicting positions. Agreement is not the forced result of dialogue. Differences in approaches, discrepancy, and confrontation go hand in hand both at the beginning and also at the end of any dialogue. The unity is in the logos, in the language, in the speech, but not in the 
conclusion. The interlocutors, the meaning, and the contradictions can vary but they never disappear completely. Even more, it is their diversity the one that constitutes the unity of the logos. Without such plurality the very logos would disappear. The unity of the speech is not the unity of the truth. Dialectics do not develop looking for more advanced explanations every time, until finding the reason of all reasons that is beyond all questioning and all reason.

In rhetoric -a part of dialectics according to Aristotle (Ret., I-2, 1356a31; I-1, 1354a1-6)- contradictory speeches also abound, as well as the most diverse intentions and senses. Audiences and speakers change constantly, also according to circumstances. The rhetorical discourse is a changing discourse and always a diverse one. If in the dialectic debate the meaning of the discourse - and the meanings of the discourses of each interlocutor - keep changing according to the gist of the communication, the same thing happens in the case of rhetorical speech, where listeners or readers keep modifying their attitude and attention as the speech progresses. The particular circumstances in which the rhetorical speech takes place - for example emotions- not only do not have to be surpassed (as in science) but they actually belong to the same argumentation.

Certainly, if the dialectic speech is marked by differences, even more so is rhetorical speech. If in dialectic speech the search for the truth is present in some way (Top.I1) in the horizon of the interlocutors (even if only with the goal of winning in the discussion using stronger arguments), conversely in rhetorical speech reference to the truth is not required at all. Diversity of meanings does not get articulated around the search for the truth, but independently from it. That is why the purpose of rhetorical speech can also be mockery, contempt, or laughter. Persuasion is not aimed towards the truth but towards action, and therefore even a lie might be its goal.

Rhetoric is directly linked to action. It is a practical reasoning that seeks concluding with the actions of the listeners. Persuasion is only a necessary way for action. Thus the central role that emotions play in Aristotelian rhetoric, since they are the ones that more easily can move to action.

The XIX and XX centuries have witnessed a certain recovery of Aristotle in different scopes (Volpi: 1999). Contemporary hermeneutics have taken a step ahead, mainly thanks to Gadamer, who has insisted on the continuity of hermeneutics with practical Aristotelian philosophy (Gadamer: 1977 y 1992). This way, Nichomachean Ethics or the Rhetoric have regained an interest that, only half a century ago, would have been unthinkable. The context is now the pragmatic dimension of language. Surprisingly, dialectics rhetoric, and in general the Aristotelian treatment of speech and discourse have progressed to occupy a relevant place in the philosophical debate of the last decades. Similar accounts have been set off from Perelman's New Rhetoric (Perelman: 1952 y 2000) or Viehweg's legal logic (Viehweg: 1986). In all those cases we find a recovery of one of Aristotle's central concerns: thinking the differences and thinking the action. 


\section{References}

Alfarabi: 1953, Catálogo de las ciencias, CSIC, Madrid.

C. d'Ancona: 1995, Recherches sur le Liber de causis, Vrin, Paris.

Aristóteles: 1970, Metafísica (Met.), Gredos, Madrid, V. García Yebra (ed.). Aristote: 1973, Physique (Phys.), Les Belles Lettres, Paris, H. Carteron (ed.).

Aristóteles: 1970, Ética a Nicómaco (EN.), Instituto Estudios Políticos, Madrid, M. Araujo y J. Marías (eds.).

Aristóteles: 1971, Retórica (Ret.), Instituto Estudios Políticos, Madrid, A. Tovar (ed.).

Aristotle: 1960, Topics (Top.), Loeb Classical Library, E.S. Forster (ed.).

Aristotle: 1987, On Sophistical Refutations (Soph. Ref.), Loeb Classical Library, E.S. Forster (ed.).

W. Beierwaltes: 1980, Identität und Differenz, Klostermann, Frankfurt a.M.

D.L. Black: 1990, Logic and Aristotle's Rhetoric and Poetics in Medieval Arabic Philosophy, Brill, Leiden.

H.G. Gadamer: 1977, La actualidad hermenéutica de Aristóteles. In: Verdad y Método, vol. I, Sígueme, Salamanca, pp. 383-396.

H.G. Gadamer: 1992, Autopresentación de Hans-Georg Gadamer, pp. 375-402; Problemas de la razón práctica, pp. 313-314. In Verdad y Método, vol. II, Sígueme, Salamanca.

Dominicus Gundissalinus: 1954, M. Alonso (ed.), De scientiis, CSIC, Madrid.

J. de Garay: 2001, La diferencia en Aristóteles. Anales de la Real Academia de Doctores, 5, 251-260.

J. de Garay: 2005, Hermenéutica y formas aristotélicas de racionalidad. In T. Oñate (ed.): Hans-Georg Gadamer: Ontología estética y hermenéutica, Dykinson, Madrid, 329-354

E. Garin: 2001, Medioevo y renacimiento, Taurus, Madrid, pp. 95-111, 155-206.

M.A. Granada: 2000, El umbral de la modernidad, Herder, Barcelona, pp. 291-324.

W.B. Hallaq (ed.): 1993, Ibn Taymiyya Against the Greek Logicians, Oxford University Press, Oxford.

G.W.F. Hegel: 1997, Lecciones de historia de la filosofía, vol. III, FCE, México.

M. Heidegger: 2002, Interpretaciones fenomenológicas sobre Aristóteles. Indicación de la situación hermenéutica. (Informe Natorp), Trotta, Madrid.

P.O. Kristeller: 1993, El pensamiento renacentista y sus fuentes, FCE, Madrid, pp. 3872, 115-149.

A. de Libera: 1993, La philosophie médiévale, PUF, Paris.

M.E. Marmura (ed.): 1997, Al-Ghazali's The incoherence of the philosophers, Brigham Young University Press, Provo (Utah).

Ch. Perelman: 1952, Rhétorique et philosophie: pour une théorie de l'argumentation en philosophie, PUF, Paris.

Ch. Perelman and L. Olbrechts-Tyteca: 2000, Tratado de la argumentación. La nueva retórica, Gredos, Madrid.

R. Radice: 1989, Platonismo e creazionismo in Filone di Alessandria, Vita e Pensiero, Milano.

Ch.B. Schmitt: 1985, La tradizione aristotélica: fra Italia e Inghilterra, Bibliopolis, Napoli.

Thomas Aquinas: 1950, Summa theologiae, I-II, q. 90 y ss., Marietti, Taurini-Romae.

Th. Viehweg: 1986, Tópica y jurisprudencia, Taurus, Madrid. 
F. Volpi: 1999, The rehabilitation of practical philosophy and neo-aristotelianism. In R.C. Bartlett y S.D. Collins (eds.): Action and contemplation: Studies in the moral and political thought of Aristotle, State University of New York, Albany, pp. 4-25.

H.A. Wolfson: 1948, Philo.Foundations of Religious Philosophy in Judaism, Christianity and Islam, Harvard University Press, Cambridge Mass. 